\title{
PUBLIC RELATIONS IN PRIVATE UNIVERSITIES IN CENTRAL JAVA: CREATING INNOVATION TO ATTRACT STUDENTS' INTEREST
}

\author{
Lina Sinatra Wijaya* \\ Public Relations Department - Faculty of Information Technology \\ Satya Wacana Christian University - Salatiga, INDONESIA \\ * Corresponding author, email: lina.sinatra@staff.uksw.edu
}

\begin{abstract}
Nowadays, The competition among private universities especially in Central Java is getting tougher. Each higher education tries to achieve their goal which is generally to attract students' interest which will influence the higher student intake in each academic year. This study tried to investigate the creative innovation created by the private university to attract students' interest which will give influence in students intake. This study employed interview and literature study for data collections. The data were then analyzed qualitatively to answer the posed research questions. This study involved 8 private universities in Central Java. The result of this study showed that the public relations role in private university is as communication technician, expert prescriber, communication facilitator and also as problem solver facilitator. Besides that, the public relations practitioners in private university have tried to create innovation program for attracting students' interest. This innovation gave positive impact on the intake of the private university at least $5 \%$ - 20\%.
\end{abstract}

Keywords: Public relations, private university, innovation.

\begin{abstract}
ABSTRAK
Sekarang ini persaingan antar universitas swasta khususnya di Jawa Tengah semakin ketat. Masing-masing perguruan tinggi mencoba untuk mencapai tujuannya yaitu menarik minat mahasiswa baru yang nantinya akan berimbas pada peningkatan jumlah mahasiswa baru yang masuk di perguruan tinggi swasta tersebut pada setiap tahun akademik. Penelitian ini mencoba untuk melihat apakah inovasi yang kreatif dari sebuah perguruan tinggi swasta dapat menarik minat calon mahasiswa baru yang nantinya akan mempengaruhi jumlah siswa yang masuk perguruan tinggi tersebut. Pengumpulan data dilakukan dengan interview dan studi pustaka. Data kemudian di analisa secara kualitatif untuk menjawab pertanyaan penelitian. Penelitian ini melibatkan 8 perguruan tinggi swasta yang ada di Jawa Tengah. Hasil dari penelitian ini menunjukkan bahwa peran seorang Public Relations di perguruan tinggi swasta adalah sebagai communication technician, expert prescriber, communication facilitator dan juga sebagai problem solver facilitator. Selain itu, public relations di perguruan tinggi swasta juga telah membuat program inovasi untuk menarik minat calon mahasiswa. Program inovasi ini memberi dampak positif pada peningkatan jumlah mahasiswa baru di universitas tersebut antara 5\%$20 \%$.
\end{abstract}

Kata kunci: Public relations, perguruan tinggi swasta, inovasi.

\section{INTRODUCTION}

In this globalization era, the use of Public relations in most of the organization and industries is not a new thing. Besides that, Because of this competitive condition, companies have to do something if they want to survive. Most companies and also government institutions use public relations to deal with communication program. The public relations of the organizations will try to make creative and effective program for the organizations. They try to understand what the public opinion is. Two way communications is applied by most industries, including higher educational institution to achieve public understanding. Why public relations is also needed in higher education institutions? Perhaps this is because education has been such a valued commodity, and people who compromise higher education institutions should know more than any other component of society given that their "product" is knowledge (Health R. L, 2000: 543). People are bombarded with information about higher educations, so as higher educations, they have to provide value by giving people information they can use, not just information that the higher educations need. Using Public relations, the higher educations can ask for and receive information just as much as they transmit it.

Furthermore, The Asean Economic Community (AEC) 2015, make higher educations especially private universities not only compete nationally but must compete regionally with other universities in 
Southeast Asia. Based on the data provided by the Association of College Administering Agency Indonesia (ABP-PTSI $=$ Asosiasi Badan Penyelenggara Perguruan Tinggi Swasta Indonesia), there are 3,385 private universities which should compete to each other to gain the prospective students (Ismail A.I, 2014), so it means the competition between private universities in Indonesia is getting tougher, especially in Central Java. Most of the private universities will try to use many kinds of media promotion in order to attract their target audiences. As a public relations officer in higher educations, many promotion activities have been done, and all of the programs done are aiming to maintain and enhance the image of the institution and building the trust from the students' as the target audiences (Wijaya L and Krismiyati, 2013: 123). Therefore the public relations bureau in each private university will do their best to achieve this purpose.

To attract the target market, the Public relations bureau of each private university generally has already done some routine programs to execute. This program might include one way communication program such as using the media advertising to advertise the institution, and also the two way communication programs such as having presentation, giving workshops, road show and also implementing the corporate social responsibilities to the stakeholders. Those programs are normally intended either reaching the society or any specific target directly or indirectly.

Seeing the fact that public relations role are very important for a university or a higher education, then it is crucial for the higher educations to really think and plan effectively and efficiently so that they can achieve their objectives and target. This condition also happens to private universities in Central Java.

\subsection{Research Questions:}

Based on the explanation above, the research question of this study is:

- What is the role of Public Relations in private universities in Central Java to attract students' interest?

- Is creating innovation program will influence in increasing the students' intake in private universities in Central Java?

\section{LITERATURE REVIEW}

It cannot be denied that nowadays most higher education institution have to compete with others to get a desirable number of students every academic year. Due to the government policy regarding student's registration and acceptance, the competition is quite tough among the universities, so the universities have to maximize their effort in attracting student's interest to enroll in their universities. These universities have used Marketing Public Relations program ranging from having presentation, participating in school exhibition to community service to support the society in building and developing their capacity and knowledge (Wijaya, L and Krismiyati, 2013 : 43). Another research stated that in some private universities in Kenya, printed media such as newspapers, brochures, alumni networks and also advertising were the most effective marketing communication tools in providing information to prospective students (Messah O B, 2011: 172). This study tries to show that creating innovation by public relations can be one of the student recruitment tools to attract the prospective students

\subsection{The Role of Public Relations}

The maintenance of an organization's reputation amongst its 'publics' is a vital corporate asset; as a result, reputation management is the core focus of public relations ( Dahlen M, Lange F and Smith T, 2010). According to Cutlip.S, Center A and Broom G (2006: 37) there are four role of public relations , they are:

a. Communication technician

Most practitioners enter the field in the communication technician role. Here someone must have communication and journalistic skills such as writing and editing employee newsletters, writing news releases and feature stories, and dealing with the media.

b. Expert prescriber

In this role, expert practitioner are seen as the authority on both public relations problems and solutions. Management leaves public relations in the hands of the "expert" and assumes a relatively passive role. Expert practitioners define the problem, develop the program and take responsibility for its implementation, with management content to get back to business as usual.

c. Communication Facilitator

The role of communication facilitator casts practitioners as sensitive listeners and information brokers. Communication facilitator serve as liaisons, interpreters and mediators between the organization and its publics.

d. Problem solving facilitator

The role of problem solving facilitator means the public relation practitioner collaborate with other managers to define and solve problems. They become part of the strategic planning team. 


\subsection{Public Relations In Higher Educations}

In this competitive situation among private universities in getting students for the university, PR has an important role for building the positive image for the community. The purpose of it is making the community confide to the university and let their children, relatives, or they themselves to study in this private university. Due to this condition the role of public relations in private universities is also different from business corporation. As what Hawkins A.G and Frohoff KM (2010) said that One of the challenges in promoting higher educations is the assumption that students are not consumers or neither are their parents. Besides, many academic and university personnel are likely to view marketing as compromising academic freedom. Additionally, universities attempt to market what is essentially a service in the same way as they market products. Universities have third party accounttability, client uncertainty, limited differences and making doers into sellers

As the University marketing function becomes more focused on standard practices such as developing and implementing formal marketing plans, establishing metrics to measure accountability and including new methods of communication in the marketing mix, it is appropriate to also review how marketing budgets are allocated among institutional initiatives, including academic programs.

\subsection{The Concept Of Innovation}

As Hornby (1995: 614) said in The Oxford Advances Learner's Dictionary, innovation means a new technique, idea etc. From this definition it can be concluded that the meaning of innovation in this study is the new technique or program done by a private university to attract students' interest. To know whether innovation has great influence for the intake, will be seen from the large number of students who re-register at the university in a particular academic year.

\section{RESEARCH METHOD}

The study involved 8 (eight) higher educations in Salatiga, Solo, Magelang, Semarang, dan Kudus in Central Java - Indonesia. The data were collected through interviewing the corresponding personnel in each institutions involved in this study. The Questions used in this study covered the following ideas:

- The Role of public relations in higher educations

- Kinds of innovation program done by public relations to increase the intake
After being collected, transcribed and analyzed, the data was interpreted to address the objective of this study. Meanwhile, the objective of this study was to know what the public relations role is in private university and also to see how "innovation " is really powerful to attract students' interest.The conventional promotion programs are considered not interesting anymore for them. They tend to switch their attention to something new. Finally, the impact on the intake of the higher educations can be identified.

For ethical consideration, the name of the interviewees and the institutions involved in this study will not be mentioned at all through out the article. It will be coded as Higher educations (HE) 1, 2, etc

\section{RESULT FINDINGS AND ANALYSIS}

\subsection{The role of Public Relations in higher educations in Central Java}

Most of the public relations practitioners in higher educations in Central Java are doing their task as communication technician where they have to know communication and journalistic skills such as writing and editing employee newsletters, writing news releases and feature stories, and dealing with the media, this mostly applied by most of the higher educations.

The promotion program such as having road show, presentation, giving workshop and joining in educational exhibition as two way process communications are still being done even though it still considered rather conventional program, but by having direct interaction with the target audiences, the message will be understood by the students clearly. Besides that most of the private universities still have cooperation with media, such as using billboard and also brochure or flier to spread the information to the target audiences. This is considered as one way communication, but students need something that can be touched or seen so that the existence of the university will always be remembered by the students.

Most of the Public relations practitioner in university have played their role as communication technician, expert prescriber where they have to define the program, execute and also evaluate the promotion programs, communication facilitator where they have to facilitate the media when they want to gain news from the higher educations and also as problem solving facilitator because they have to collaborate with the manager in solving the problems. All of this are done in order to make the promotion program 
become more creative and challenging for new students. In playing their role, they also have to be creative in making their programs become the ones attracted by high schools students.

\subsection{The Innovation public relations program}

Based on the interview done to 8 public relations of higher educations in Central Java, most of them have already created innovative programs which have been applied in to their target audiences.

The innovation done by the higher educations in Central Java can be seen from the data gathered form 8 higher educations which are summarized as follows.

Table 1. Innovation done by Private Universities (PU)

\begin{tabular}{|c|c|c|c|}
\hline $\mathrm{NO}$ & $\begin{array}{l}\text { University/ } \\
\text { Higher } \\
\text { Education }\end{array}$ & Innovation Programs & $\begin{array}{l}\text { Increase } \\
\text { on the } \\
\text { Intake }\end{array}$ \\
\hline 1 & PU 1 & $\begin{array}{l}\text { - Free laptop for highschools } \\
\text { that can constribute at least } \\
20 \text { students } \\
\text { - Mobile Registration and } \\
\text { Test (bus service) }\end{array}$ & $20 \%$ \\
\hline 2 & PU 2 & $\begin{array}{l}\text { - Coorperation with } \\
\text { Highschool concelling } \\
\text { teachers in getting new } \\
\text { students }\end{array}$ & None \\
\hline 3 & PU 3 & $\begin{array}{l}\text { - Talkshow created by } \\
\text { involving university } \\
\text { students and also alumni in } \\
\text { the talkshow }\end{array}$ & $10 \%$ \\
\hline 4 & PU 4 & $\begin{array}{l}\text { Social media was tackled } \\
\text { by one person } \\
\text { - Student care } \rightarrow \text { helping } \\
\text { new students to find } \\
\text { boarding house }\end{array}$ & $10 \%$ \\
\hline 5 & PU 5 & $\begin{array}{l}\text { - Giving } 1 \text { scholarship for } \\
\text { highschool teacher studying } \\
\text { in } \mathrm{S} 2 \text { degree but, they have } \\
\text { to get at least } 20 \text { students } \\
\text { - Top } 10 \text { of the students from } \\
\text { the highschools will be } \\
\text { given discount }\end{array}$ & $10 \%$ \\
\hline 6 & PU 6 & $\begin{array}{l}\text { Encouraging in using the } \\
\text { social media effectively. }\end{array}$ & $10 \%$ \\
\hline 7 & PU 7 & $\begin{array}{l}\text { - Enlarging media coverage } \\
\text { especially radio. }\end{array}$ & $10 \%$ \\
\hline 8 & PU 8 & $\begin{array}{l}\text { Free pick up service for } \\
\text { new students from two } \\
\text { airports (semarang and } \\
\text { Jogya) }\end{array}$ & $5-10 \%$ \\
\hline
\end{tabular}

Eight private universities have shown that they have created their innovative program to attract students' interest. Giving free laptop to highschools which were able to send at least 20 students to register in this higher education (PU 1), giving scholarship for highschools which were able to send at least 20 students (PU 5) are also a great challenge for the highschools . Highschools will compete themselves in sending their students to study there. Besides that, this PU 1 also provide mobile registration and test bus that will go to schools which have students who want to register. This innovative idea has great influence on the intake of the university. Other university also had an idea of having an interactive talkshow by involving the active student to be the resource person in the radio (PU 3), and enlarging the media coverage especially radio (PU 7) . By having active students in the interactive talkshow would motivate highschool students to ask questions to make sure they were not wrong in choosing a place to continue their study. There were also two private universities (PU 4 and PU 6) that think that social media was the best way to attract students' interest toward the higher educations. To make the social media became an effective way in giving information to students, public relations of the universities place a staff to handle this social media so that the information would be centered to one person. The last innovative program was a little bit different from the other private universities, that was providing pick up service for new students who were accepted to study in this higher education (PU 8). By having a free pick up service in two airports (Semarang and Jogyakarta) the new students especially the ones who comes from outsite java islands, and also parents do not have to worry because the staff from the higher education and will pick and lead them to their boarding houses.

From what the Private universities have done, the impact on intake of the private universities can be identified, eventhough there is also a university which did not show any improvement in the intake (PU 2) due to the innovative program created by the university was not really a challenging one for their target audience

\section{DISCUSSION}

From the findings, it shows that the role of public relations practitioners in private universities are completely different from the role of public relations in business corporations. All higher educations involved in this study have their own Public Relations practitioners. These private university generally emphasize the role of Public Relations in terms of maintaining good relationship with their stakeholders like high schools, media, prospective students, 
parents, society and many more. The public relations practitioners in these higher educations focussed on the programs that aim at increasing the number of the students register in the university.

The public relations practitioner in private university must have good relations with press and media whether it is printed media or electronic media, because the influence of media in brand imagery and affecting consumer perceptionss is huge and needs careful managing if brand equity is to be maintained (Dahlen, M., Lange, F. and Smith, T. : 2010). This shows that the image of the higher educations depends on how good their relations with the press and media.

Higher educations are considered as non profit organizations so as public relations practitioner, their goal are not the same as those of corporations. Nonprofits seek to win public support of their mission and programs through active and open communication, and also seek to broaden volunteer participation in their efforts (Sitel, F. : 1995). In this condition the public relations practitioners in private universities in Central Java tend to be good communication facilitators and problem solver facilitators (Cutlip, S., Center, A., and Broom, G., 2006 : 41) where they have to be active and open to their public so that they will get the support from their public. The Public relations practitioners in the higher educations will become the liason between the higher education and its public and together with the management of the higher educations will create a strategic plan for the success of their program.

To become exist in this educational worlds, the public relations practitioners of these private universities have to be creative in making their promotion program. Not only doing the conventional promotion program such as presentation, roadshow, educational expo and advertising, A public relations practitioner of a higher educations should also be an expert prescriber. It means that the public relations practitioners of this higher educations have to create an innovation program to attract students' interest. Most of the public relations practitioners in these private universities in Central Java have tried their best to come up with innovation in their promotion program each year. As what Chesbrough H. (2005: 2) said that open innovation suggests that valuable ideas can come from inside or outside the company and can go to market from inside or outside the company as well. So as public relations practitioner of higher educations should be creative in making innovation, they act as expert prescribers who always try to create innovative programs for promotion so that the intake of the higher educations will increase. By having creative innovation program, the students will be interested to know more about these private universities

\section{CONCLUSION}

To conclude with, this study has successfully answered the research questions, Firstly, all the public relations practitioners in higher educations institution have already played their role as communication technician, expert prescriber, communication facilitator and also as problem solver facilitator to attract their target audiences and to create good reputation of the higher educations. Secondly, most of the private universities know that having innovation every academic year will give new nuance and also new challenging for the target audiences. Finally, the innovation programs they have created have big influence in their intake eventhough there is also higher education that does not get any improvement in the intake, but this is due to the innovative program is not really a challenging one for the target audience. Hopefully by having new innovation every year will become a good challenge for both parties, the higher education itself and also the target audience.

\section{REFERENCES}

Chesbrough, H. (2006) Open innovation: A new Paradigm for understanding Industrial innovation, Oxford Universtity Press, London

Cutlip, S., Center, A., and Broom, G. (2006) Effective Public Relations, $9^{\text {th }}$ edition, New Jersey: Pearson Prentice Hall

Daglen, M., Lange, F., and Smith, T, (2010) Marketing Communication, John Wiley \& Sons Ltd, Spain.

Hawkins, A.G. and Frohoff, K.M. (2010) Promoting the academy-the challenges of marketing, Research in Higher Education Journal.

Health R. L. (2000) Handbook of Public Relations, Sage publication, inc, The United States of America.

Hornby, A. S. (1995), Oxford Advanced Learner's Dictionary, $5^{\text {th }}$ ed, Oxford University Press. Great Britain.

Ismail, A. I. (2014) PTS and MEA 2015, www. Republika.co.id, 15 Desember 2014

Messah, O. B. (2011) Effect of Selected Marketing Communication Tools on Student Enrolment in Private Universities in Kenya, European Journal of Business and Management, 3(3). 
Seitel, F. P. (April 1995) The Practice of Public Relations, Prentice Hall Inc, the United States of America

Wijaya, L. and Krismiyati (2013) Identifying Marketing Public Relations Strategies implemented in Private Universities for Increasing Students intake in Central Java - Indonesia, Research world - Journal of Art, Science and Commerce, IV(2), 43-49.

Wijaya L and Krismiyati (2013) “MPR Strategies Modeling for Increasing Students' intake At Private Universities In Central Java - Indonesia ", Research world -Journal of Art, Science and Commerce, Vol IV issue 3 - July page 122-129 